\title{
LIFE SATISFACTION IN WOMEN AFTER MASTECTOMY - A PILOT STUDY
}

\section{SATYSFAKCJA ŻYCIA U KOBIET PO MASTEKTOMII - BADANIE PILOTAŻOWE}

\author{
Monika Szpringer ${ }^{1(\mathrm{~A}, \mathrm{E}, \mathrm{F}, \mathrm{G})}$, Justyna Kaczmarczyk ${ }^{1(\mathrm{~B}, \mathrm{C}, \mathrm{D}, \mathrm{E})}$, Dominika Bomba ${ }^{2(\mathrm{~B}, \mathrm{C}, \mathrm{D}, \mathrm{E})}$, \\ Edyta Laurman-Jarząbek ${ }^{3(B, C, D, E)}$, Jarosław Chmielewski ${ }^{4(B, C, D)}$, \\ Magdalena Florek-Luszczki ${ }^{(B, C, D, E, F)}$, Jarogniew J. Luszczki ${ }^{6,7(D, E, F)}$
}

\author{
${ }^{1}$ Faculty of Medicine and Health Sciences, Jan Kochanowski University in Kielce, Poland \\ ${ }^{2}$ Faculty of Social Sciences, John Paul II Catholic University of Lublin, Poland \\ ${ }^{3}$ Faculty of Education, Jesuit University Ignatianum in Krakow, Poland \\ ${ }^{4}$ Institute of Environmental Protection - National Research Institute in Warsaw, Poland \\ ${ }^{5}$ Department of Medical Anthropology, Institute of Rural Health in Lublin, Poland \\ ${ }^{6}$ Department of Pathophysiology, Medical University of Lublin, Poland \\ ${ }^{7}$ Isobolographic Analysis Laboratory, Institute of Rural Health in Lublin, Poland
}

Authors' contribution Wkład autorów:

A. Study design/planning zaplanowanie badań

B. Data collection/entry zebranie danych

C. Data analysis/statistics dane - analiza i statystyki D. Data interpretation interpretacja danych E. Preparation of manuscript przygotowanie artykułu F. Literature analysis/search wyszukiwanie i analiza literatury G. Funds collection zebranie funduszy
Tables: 3

Figures: 0

References: 19

Submitted: 2018 Aug 7

Accepted: 2018 0ct 17

\section{Summary}

Background. Cancer is the second most common cause of morbidity and mortality in Poland and breast cancer is the most frequent malignant neoplasm occurring in Polish women. The aim of this paper is to analyse life satisfaction in women after mastectomy.

Material and methods. The pilot study comprised of women with breast cancer after mastectomy and women in a good overall health.

Results. On the basis of the conducted studies, it may be stated that women after mastectomy have a similar life satisfaction level as healthy individuals. The statistically relevant differences have been obtained only in some subscales related to leisure time, residence and parenting attitude.

Conclusions. More detailed studies are required to elucidate some subtle differences in life satisfaction between women after a mastectomy and healthy women.

Keywords: breast cancer, mastectomy, life satisfaction

\section{Streszczenie}

Wprowadzenie. Nowotwory są drugą najczęstszą przyczyna zachorowalności i umieralności w Polsce, a rak piersi jest najczęstszym nowotworem złośliwym występującym w populacji Polek. Celem pracy jest analiza zadowolenia z życia u kobiet po mastektomii.

Materiał i metody. Badaniem pilotażowym objęto kobiety z rakiem piersi po mastektomii oraz kobiety w dobrym stanie zdrowia.

Wyniki. Na podstawie przeprowadzonych badań można stwierdzić, że kobiety po mastektomii mają podobny poziom zadowolenia z życia, co kobiety zdrowe. Istotne statystycznie różnice uzyskano tylko w niektórych podskalach związanych z czasem wolnym, miejscem zamieszkania i stosunkiem do własnych dzieci.

Wnioski. Potrzebne są bardziej szczegółowe badania, aby wyjaśnić pewne subtelne różnice w satysfakcji życiowej kobiet po mastektomii i u zdrowych kobiet.

Słowa kluczowe: rak piersi, mastektomia, zadowolenie z życia

\section{Introduction}

Breast cancer is one of the commonest malignant neoplasms in women in Poland. It accounts for approximately $25 \%$ of all cancer morbidities and $14 \%$ of cancer-caused deaths [1]. Epidemiological data indicates that about 1.5 million women across the world are diagnosed with breast cancer every year, of which 400,000 die as a result of the disease. Breast cancer is the commonest malignant neoplasm in female populations in highly developed countries such as the US, Canada, Australia and Western Europe. The lowest number of breast cancer incidents

Address for correspondence / Adres korespondencyjny: Jarogniew J. Łuszczki, Department of Pathophysiology, Medical University of Lublin, Jaczewskiego 8b, 20090, Lublin, Poland, e-mail: jarogniew.luszczki@umlub.pl, phone: +48 814486500

ORCID: Monika Szpringer https://orcid.org/0000-0002-6510-5714, Justyna Kaczmarczyk https://orcid.org/0000-0002-9427-9449,

Dominika Bomba https://orcid.org/0000-0002-0840-9017, Edyta Laurman-Jarząbek https://orcid.org/0000-0002-4664-0607,

Jarosław Chmielewski https://orcid.org/0000-0003-2606-1656, Magdalena Florek-Łuszczki https://orcid.org/0000-0003-1489-2399,

Jarogniew J. Łuszczki https://orcid.org/0000-0002-3059-0393

Copyright: (C) Pope John Paul II State School of Higher Education in Biała Podlaska, Monika Szpringer, Justyna Kaczmarczyk, Dominika Bomba, Edyta LaurmanJarząbek, Jarosław Chmielewski, Magdalena Florek-Łuszczki, Jarogniew J. Łuszczki. This is an Open Access journal, all articles are distributed under the terms of the Creative Commons Attribution-NonCommercial-ShareAlike 4.0 International (CC BY-NC-SA 4.0) License (http://creativecommons.org/licenses/by-nc-sa/4.0/), allowing third parties to copy and redistribute the material in any medium or format and to remix, transform, and build upon the material, provided the original work is properly cited and states its license. 
are recorded in South-Eastern Asia and Africa. Although it is one of the most common cancer types in women, it rarely occurs in men [2].

Increasing cases of breast cancer are being observed in Poland, with a more than two-fold increase breast cancer-related morbidity during the last 30 years. The greatest morbidity risk is identified within menopauseand post-menopausal women [3]. The majority of deaths caused by malignancies occur in people aged over 50 years (National Cancer Register). The estimated data suggest that the incidence of breast cancer will exceed 21,000 cases per year during the upcoming 15 years [1].

A long-term programme has been introduced in Poland, aimed at managing cancer. It was called "The National Programme for Combating Neoplastic Diseases, 2016-2024", and was supervised and executed by a respective health minister and financed from a state budget [4].

Amongst the most significant causes of breast cancer are age, hormones, genetics and diet $[1,3,5]$. Over the age of 35 , the frequency of breast cancer increases rapidly. Studies reveal that in women subjected to prophylactic screening mammography tests, the risk decreases in approximately one-third of patients [6]. The advancement in civilisation allows for developing new and increasingly efficient methods of combating cancer diseases.

One of the oldest methods for treating breast cancer is surgical. Mastectomy (breast removal) leaves women having to re-adapt to a new situation and re-evaluate life satisfaction. After breast removal, some women feel an extensive sense of disability caused by a negative attitude from their spouse. This impedes a women's adaptation to the disease, self-acceptance and return to normal life [7, 8].

It has been observed that young and married women with children are relatively less concentrated on their altered physical appearance and more concentrated on regaining health and general physical fitness. According to some authors [9], young and single women are more concerned about their body image and loss of feminine attributes. A role is also played by the importance perceived by patients of their physical appearance before the disease.

Breast removal does not preclude sexual activity if both partners are willing. It must be stressed, however, that post-surgical scars may induce negative reactions from partners. With time, partners usually adapt to this new situation, but woman's behaviour is also important in such circumstances [8]. The range and intensity of social activities undertaken by a woman after mastectomy are determined by her natural needs as well as her physical and mental health [8]. For women after mastectomy, social activity is not only a cultural pastime, but also an important component of social belonging and general life satisfaction.

The aim of the paper is to assess the life satisfaction levels in women after mastectomy, compared to women in a control group who do not have breast cancer.

\section{Material and methods}

The study group comprised of women with breast cancer, and the control group included women without breast cancer who declared a good health. The study in the first group was conducted following surgical treatment; the women were associated in Amazons clubs (women after mastectomy) in the Świętokrzyskie region. Women from the control group were residents from the same region. In total, 80 questionnaire sets were distributed. Since numerous questions were replied to incompletely (in particular from the study group), only 60 full sets that met the completeness and correctness criteria were included in the final analysis of this pilot study. Out of those 60 sets, 30 were obtained from the study group (women with breast cancer), and 30 from the control group (healthy women between 30-60 years-old). The average ages in both groups were similar: $47.6 \pm 9.93$ years-old for the study group, and $43.8 \pm 9.57$ years-old for the control group.

The respondents were selected randomly and voluntarily, and remained anonymous. Personal details as well as the social and demographic data recorded from the respondents included information about their age, marital status, place of residence, social and professional status, education level, attitudes towards religion, and satisfaction towards their marital status and residence.

The results indicate that marital status was not a differentiating element between groups, with the majority of married women (85\%), divorced (6.7\%) and widowed $(6.7 \%)$ respondents.

The data reveals that the majority of study group respondents live in towns, including $46.7 \%$ in medium-sized towns. Similar numbers apply to the control group, where $43.3 \%$ live in medium-sized towns. In contrast, $33.3 \%$ of respondents from the study group live in large cities, whereas the $33.3 \%$ of respondents from the control group live in villages. Statistical analysis of data revealed that the examined variable does not differentiate the analysed groups $\left(\chi^{2}=12.73, \mathrm{df}=3, \mathrm{p} \leq 0.05\right)$.

The results of the study indicate that in terms of education level, most women attained higher level of education (63.3\% in the study group vs. $36.6 \%$ in the control group). The number of women with primary, secondary and 
vocational levels of education were similar in both groups (results not shown). The results also indicate that both groups demonstrate similar religious views, with $73.3 \%$ and $93.3 \%$ believers in the study group and the control group, respectively (results not shown). Only one person refused to provide her answer on this matter.

The data suggests that more than half of participants both in the study and control groups (53.3\% and $56.7 \%$, respectively) deem their residential status as satisfactory, and more than $30 \%$ of respondents from both groups perceive their residential status as very good. The results indicate that this variable does not introduce a statistically relevant differentiation between the groups $\left(\chi^{2}=0.73, \mathrm{df}=1, \mathrm{p} \leq 0.05\right)$. The majority of women surveyed in the study (76.7\%) and in the control groups (66.7\%) viewed their material status as either very good or satisfactory. In this study, we used the Life Satisfaction Questionnaire, originally developed in 1998 by Fahrenberg, Myrek, Schumacher and Brahler.

The questionnaire comprised 10 scales: 1) health - demonstrates satisfaction with general somatic health, mood, mental agility, immunity to disease; and how frequently an individual experiences pain and illness; 2 ) job and profession - this scale comprises satisfaction with their professional status at the workplace, certainty about future career, achievements at work, possible promotions, atmosphere at the workplace, scale of duties and requirements at work, as well as diversity provided by one's profession; 3) financial situation - expresses satisfaction with their standard of living, security of one's financial situation, future earnings, opportunities that may be provided to one's family as a result of their financial status, as well as financial security at an older age; 4) leisure time - involves satisfaction with the number of days off per year, free time in the afternoons and at weekends, the quality of leisure during free time, the amount of time spent with family and the variety of leisure time activities; 5) marriage and partnership - this scale comprises satisfaction with marriage or partnerships, their common activities together, satisfaction with partner's honesty, consideration, gentleness and support provided and their readiness to help; 6) parenting attitude (towards their own children) - applies to satisfaction with living with children, taking part in their school and professional successes, the joy given by children, the effort given to looking after their children, their ability to influence them, the respect received by their children and common activities shared; 7) personal satisfaction - this scale comprises satisfaction with their own skills, the way respondents spent their lives, physical appearance, confidence, their uniqueness, vitality and entering into relations with people; 8) sexuality - expresses satisfaction with physical attractiveness, sexual activity, frequency of sexual intercourse with a partner, with own sexual reactions, with the ability to have honest conversations about sexual issues, as well as sexual consistence between the respondent and her partner; 9) friends, colleagues, relatives - this scale involves satisfaction with one's circle of friends and acquaintances, contact with relatives and neighbours, help and support provided by friends and colleagues, their activity in associations, organisations and engaging in social relations and frequency of spending time with people; 10) residence - this involves satisfaction with the size, standard and status of one's residence, the expenses required to maintain it, their location, connections provided by public transport and noise level.

\section{Results}

Based on the Life Satisfaction Questionnaire, it was found that in the "leisure time" subscale, the average results for women with cancer was 36.06, whereas for the control group was 31.26, which was statistically significant $(\mathrm{P}<0.05$ (Table 1)).

Table 1. Independent trials testing significance of differences between averages

\begin{tabular}{|c|c|c|c|c|c|c|}
\hline \multirow{2}{*}{ Life Satisfaction Questionnaire } & \multicolumn{2}{|c|}{ Study group } & \multicolumn{2}{c|}{ Control group } & \multirow{2}{*}{ F-statistics } & \multirow{2}{*}{ P-value } \\
\cline { 2 - 7 } & Mean & S.D. & Mean & S.D. & & 0.316 \\
\hline Health & 30.20 & 7.53 & 35.60 & 7.36 & 1.02 & 0.809 \\
\hline Job and profession & 36.20 & 6.24 & 35.63 & 6.50 & 0.06 & 0.38 \\
\hline Financial situation & 28.96 & 8.42 & 29.46 & 8.68 & 0.540 \\
\hline Leisure time & 36.06 & 4.66 & 31.26 & 7.67 & 6.97 & $\mathbf{0 . 0 1 0}$ \\
\hline Marriage / relationships & 37.63 & 7.49 & 36.90 & 8.66 & 0.04 & 0.838 \\
\hline Parenting attitude & 39.56 & 6.67 & 41.73 & 3.85 & 5.48 & $\mathbf{0 . 0 2 2}$ \\
\hline Personal satisfaction & 36.50 & 5.45 & 36.60 & 7.33 & 2.66 & 0.108 \\
\hline Sexuality & 31.86 & 9.16 & 33.23 & 8.47 & 0.70 & 0.406 \\
\hline Friends, colleagues, relatives & 36.50 & 3.90 & 35.26 & 7.09 & 2.23 & 0.140 \\
\hline Residence & 34.13 & 7.62 & 35.33 & 5.27 & 4.39 & $\mathbf{0 . 0 4 0}$ \\
\hline General life satisfaction & 347.63 & 45.84 & 351.03 & 50.54 & 0.01 & 0.926 \\
\hline
\end{tabular}


This indicates statistical differences between the satisfaction with the personal leisure time demonstrated by women with breast cancer and those who are disease-free. The latter group are more satisfied with their leisure time and how they spend it (Table 1). There were statistically significant differences between the average results in the parental attitude towards their own children subscale $(\mathrm{P}<0.05)$. Women in the study group were less happy with their children, with the effort made to raise them and with the perceived respect their children show to them than the women from the control group (Table 1). Women with breast cancer are less happy with their residence, its location and the expenses required to maintain it $(\mathrm{P}<0.05)$, than the women from the control group (Table 1). The above data reveals that positive correlations may be found in healthy women between satisfaction with health and specific subscales. The strongest correlation $(r=0.795, \mathrm{P}<0.001)$ occurs between satisfaction with health and general life satisfaction (Table 2). This may indicate that satisfaction with one's health in the control group may have an impact upon their general life satisfaction.

Table 2. The Pearson's r correlation between the "life satisfaction" subscale and particular subscales of the Life Satisfaction Questionnaire

\begin{tabular}{|c|c|c|c|c|}
\hline \multirow{2}{*}{ Life Satisfaction Questionnaire } & \multicolumn{4}{|c|}{ Health } \\
\cline { 2 - 5 } & \multicolumn{2}{|c|}{ Study group } & \multicolumn{2}{c|}{ Control group } \\
\cline { 2 - 5 } & $\mathbf{r}$ & P-value & $\mathbf{r}$ & 0.000 \\
\hline Health & 0.026 & 0.890 & 0.644 & 0.013 \\
\hline Job and profession & 0.239 & 0.203 & 0.450 & 0.002 \\
\hline Financial situation & -0.183 & 0.333 & 0.539 & 0.006 \\
\hline Leisure time & 0.278 & 0.137 & 0.494 & 0.010 \\
\hline Marriage / relationships & 0.005 & 0.788 & 0.461 & 0.000 \\
\hline Parenting attitude & 0.456 & 0.011 & 0.635 & 0.002 \\
\hline Personal satisfaction & 0.543 & 0.002 & 0.550 & 0.002 \\
\hline Sexuality & -0.111 & 0.558 & 0.551 & 0.180 \\
\hline Friends, colleagues, relatives & 0.153 & 0.419 & 0.251 & 0.000 \\
\hline
\end{tabular}

Satisfaction with health also correlates positively with general life satisfaction in women with breast cancer $(r=0.425, \mathrm{P}<0.05)$, however this is a moderate correlation and not as strong as that of the control group (Table 2). In the group of women with breast cancer, there is a high positive correlation between general life satisfaction ( $r=0.837, \mathrm{P}<0.001)$ and satisfaction with their marriage or relationship (Table 3 ). This may be defined as a successful marriage (relationship), receiving support and a sense of safety provided by their partner as a source of satisfaction for women with breast cancer. A positive correlation is also noted between these variables in women from the control group, but not as strong as the study group $(\mathrm{r}=0.680, \mathrm{P}<0.001)$.

Table 3. The Pearson's r correlation between the general life satisfaction and particular subscales of the Life Satisfaction Questionnaire

\begin{tabular}{|c|c|c|c|c|}
\hline \multirow{2}{*}{ Life Satisfaction Questionnaire } & \multicolumn{4}{|c|}{ General life satisfaction } \\
\cline { 2 - 5 } & $\mathbf{2}$ & Ptudy group & \multicolumn{2}{c|}{ Control group } \\
\cline { 2 - 5 } & $\mathbf{r}$ & 0.001 & 0.681 & 0.000 \\
\hline Health & 0.566 & 0.000 & 0.677 & 0.000 \\
\hline Job and profession & 0.812 & 0.029 & 0.737 & 0.000 \\
\hline Financial situation & 0.398 & 0.000 & 0.680 & 0.000 \\
\hline Leisure time & 0.837 & 0.000 & 0.566 & 0.000 \\
\hline Marriage / relationships & 0.700 & 0.000 & 0.849 & 0.001 \\
\hline Parenting attitude & 0.836 & 0.000 & 0.787 & 0.000 \\
\hline Personal satisfaction & 0.772 & 0.025 & 0.766 & 0.000 \\
\hline Sexuality & 0.409 & 0.000 & 0.443 & 0.000 \\
\hline Friends, colleagues, relatives & 0.817 & 0.019 & 0.795 & 0.014 \\
\hline
\end{tabular}

The general life satisfaction in women from the control group is strongly and positively influenced by being satisfied with oneself $(\mathrm{r}=0.836, \mathrm{P}<0.001)$, satisfaction with their residence $(\mathrm{r}=0.817, \mathrm{P}<0.001)$, satisfaction with financial status $(\mathrm{r}=0.812, \mathrm{P}<0.001)$ and satisfaction with sexuality $(\mathrm{r}=0.772, \mathrm{P}<0.001)$. Hence women 
with breast cancer are satisfied with life if they have decent residential and financial statuses, are happy with their skills, the way they spend their life, their physical appearance and that they trust themselves. It seems that a positive perception of one's life by these women is significantly influenced by their physicality, attractiveness, sexual activity and frequent intimate intercourse. This appears fair considering the very nature of their disease. If breast cancer does not impede a women's physical appearance, attractiveness or ability to engage in sexual activity, then such women are satisfied with their lives. In the group of healthy women, there is a positive strong correlation between life satisfaction and being happy about oneself $(r=0.849, \mathrm{P}<0.001)$, satisfaction with one's health $(r=0.795, \mathrm{P}<0.001)$, satisfaction with one's sexuality $(\mathrm{r}=0.787, \mathrm{P}<0.001)$, satisfaction with their contact with friends and relatives $(\mathrm{r}=0.766, \mathrm{P}<0.001)$, and satisfaction with one's leisure time $(\mathrm{r}=0.737, \mathrm{P}<0.001)$. There are noticeable differences between the variables which strongly influence general life satisfaction in women with breast cancer and healthy women. For instance, there is a weak positive correlation between the "leisure time" variable and general life satisfaction $(r=0.398, \mathrm{P}<0.05)$ in the study group, whereas in healthy women, this variable is a strong predictor of general life satisfaction.

\section{Discussion}

The results presented in this study show there are no statistically relevant differences between general life satisfaction levels in women with breast cancer and that in healthy women. Some statistically relevant differences may be found in specific subscales, such as leisure time, parenting attitude or place of residence. Women with breast cancer are more satisfied with their leisure time and the way they spend it, but less satisfied than healthy women with their relations with children, the support received from them, their children's school achievements and how their children are influenced by them. Women after mastectomy are also less happy about their residence, including the expenses incurred to maintain it, location, noise pollution level and living standard.

Cancer is often a source of heavy stress to any individual experiencing it, thus influencing their entire functioning and integrity $[10,11]$. During chemotherapy, quality of life in patients with breast cancer deteriorates [12]. A higher subjective sense of the disease correlated with lower general level of life quality [13].

Various studies demonstrate that symptoms of depression are common in patients with cancer $[11,15,16]$. This is why a multi-faceted social support is an essential factor in facilitating acceptance of the disease and positive adaptation to a difficult condition, thereby influencing life satisfaction [17]. The latter may be defined as a subjective experience of well-being by an individual [18].

Based on this study, it may be stated that both women after breast removal and healthy controls demonstrate a similar general life satisfaction level. Only some of the subscales have shown statistically relevant differences (Table 3). The respondents from both groups are least happy about their financial situations, their properties, income, life standards and financial security for the future. As presented in the subject-matter literature, the patients receiving support in Amazon Clubs are generally able to accept the disease better than women who are not associated with such clubs [19]. The selection of the study group (only those who received such support) may have resulted in the similarities between life satisfaction levels in sick and healthy women. Also important is the time passed since the mastectomy - at least five years, which may cause the differences between the test and the control groups to be non-significant.

\section{References:}

1. Didkowska J, Wojciechowska U. [Breast cancer in Poland and Europe - population and statistics]. Nowotwory. Journal of Oncology. 2013; 63(2): 111-118 (in Polish).

2. National Cancer Registry [Internet]. Warszawa: Zakład Epidemiologii i Prewencji Nowotworów, Centrum Onkologii - Instytut. [Breasts cancer in women] [cited 2018 Jul 30]. Available from: http://onkologia.org.pl/rak-piersi-kobiet/ (in Polish).

3. Kowalczyk A, Kozłowska E, Dąbska O, Wołoszynek E. [Epidemiology of malignant tumors among Polish women in peri- and postmenopausal period in 1999-2012]. Pielęgniarstwo i Zdrowie Publiczne. 2017; 2(2): 101-106 (in Polish). https://doi.org/10.17219/pzp/64681

4. INFOR.PL [Internet]. Warszawa: INFOR PL S.A. [Resolution No. 208 of the Polish Council of Ministers of November 3, 2015] [cited 2018 Jul 30]. Available from: http://www.infor.pl/akt-prawny/ MP0.2015.210.0001165,uchwala-nr-208-rady-ministrow-w-sprawie-ustanowienia-programuwieloletniego-na-lata-20162024-pod-nazwa-narodowy-program-zwalczania-chorob-nowotworowych. html (in Polish). 
5. Tuchowska P, Worach-Kardas H, Marcinkowski JT. [The most common malignant tumors in Poland - the main risk factors and the possibilities of optimizing preventive actions]. Problemy Higieny i Epidemiologii. 2013; 94(2): 166-171 (in Polish).

6. Zatoński W. European code against cancer: third version (2003). Kraków: Medycyna Praktyczna; 2007.

7. Turuk-Nowakowa T. [Psychologist's behavior in cancer]. In: Heszen-Niejodek I, editor. [Role of a psychologist in the diagnosis and treatment of somatic diseases]. Warszawa: Wydawnictwo Lekarskie PZWL; 1990 (in Polish).

8. Mika AK. [After breast amputation]. Warszawa: Wydawnictwo Lekarskie PZWL; 1999 (in Polish).

9. De Walden-Gałuszko K, Majkowicz M, Trojanowski L, Trzebiatowska I. [Quality of life in women with breast cancer]. In: de Walden-Gałuszko K, Majkowicz M, editors. [Quality of life in cancer]. Gdańsk: Wydawnictwo Uniwersytetu Gdańskiego; 1994 (in Polish).

10. Wybraniec-Lewicka B, Szpringer M, Czerwiak G, Michalska M, Ciura E. [The lifestyle of women after mastectomy]. Studia Medyczne. 2008; 10: 27-30 (in Polish).

11. Stępień R, Wrońska I. [Anxiety and depression as emotional determinants of functional capabilities of women after radical treatment of breast cancer]. Studia Medyczne. 2008; 10: 31-35 (in Polish).

12. Puchalska M, Sierko E, Sokół M, Wojtukiewicz MZ. [The quality of life of patients with breast cancer who underwent chemotherapy in a hospital setting]. Problemy Pielęgniarstwa. 2011; 19(3): 341-347 (in Polish).

13. Guzińska K, Dziedziul J, Rudnik A. [Psychological conditions of the quality of life of patients undergoing radiotherapy with regard to the stage of the disease and age]. Psychoonkologia. 2014; 2: $51-58$ (in Polish).

14. Sabiston CM, Lacombe J, Faulkner G, Jones J, Trinh L. Profiling sedentary behavior in breast cancer survivors: links with depression symptoms during the early survivorship period. Psycho-Oncology. 2018; 27(2): 569575. https://doi.org/10.1002/pon.4520

15. Mazurek E. [Breast cancer and emotions. Spouses facing a decision of breast reconstruction]. Przegląd Pedagogiczny. 2016; 2: 227-240 (in Polish).

16. Malicka I, Szczepańska J, Anioł K, Rymaszewska J, Woźniewski M. [Mood disorders and strategies for adapting to the disease in women treated surgically for breast and reproductive cancer]. Współczesna Onkologia. 2009; 13(1): 41-46 (in Polish).

17. Kabała M. [Analysis of the level of received social support among women after mastectomy]. In: Szpringer M, Wojciechowska M, Chmielewski J., editors. [Inderdisciplinary aspects of modernity]. Warszawa: Instytut Ochrony Środowiska - Państwowy Instytut Badawczy; 2016. p. 181-193 (in Polish).

18. Pasik M. [Sense of coherence and life satisfaction in men and women in retirement]. Acta Universitatis Lodziensis. Folia Psychologica. 2007; 11: 67-79 (in Polish).

19. Malicka I, Szczepańska-Gieracha J, Jankowska E, Woźniewski M, Rymaszewska J. Physical activity, life satisfaction and adjustment to illness in women after treatment of breast cancer. Współczesna Onkologia. 2011; 15(3): 180-185. https://doi.org/10.5114/wo.2011.23011 